\title{
Experimental study on the anti-jacking-up performance of a screw pile for photovoltaic stents in a seasonal frozen region"
}

\author{
Teng-fei WANG ${ }^{1}$, Jian-kun $\mathrm{LIU}^{\dagger+1}$, Hua-gang ZHAO ${ }^{1}$, Ya-long SHANG ${ }^{2}$, Xiao-qiang LIU $^{1}$ \\ $\left({ }^{1}\right.$ School of Civil Engineering, Beijing Jiaotong University, Beijing 100044, China) \\ $\left({ }^{2}\right.$ North China Power Engineering Co., Ltd. of China Power Engineering Consulting Group, Beijing 100011, China) \\ ${ }^{\dagger}$ E-mail: jkliu@bjtu.edu.cn
}

Received June 1, 2016; Revision accepted June 15, 2016; Crosschecked June 15, 2016

\begin{abstract}
The soils in seasonal frozen regions freeze and thaw frequently, causing severe frost heave and thaw settlement problems, which bring challenges to piles of photovoltaic stents. In this paper, laboratory tests are conducted with different types of screw piles under freezing conditions, with also using smooth piles for contrast. The aim is to simulate the freezing process of screw piles according to practical working conditions based on the similarity principle. Internal thermal resistance is ignored. The change laws of temperature, displacement, as well as the influence factors of types of screw piles are analyzed. The results indicate that: with a freezing depth of $30 \mathrm{~cm}$, which is half of the pile length, large-double-bladed screw piles perform the best in antijacking-up, while all-bladed screw piles perform the worst, independent of the types of soil samples tested. The fitting relationship between jacking-up displacement and freezing depth is also proposed for each type of pile. Results obtained can provide an important reference to site construction in seasonal frozen regions.
\end{abstract}

Key words: Seasonal frozen region, Screw pile, Frost heave, Similarity principle, Jacking-up http://dx.doi.org/10.1631/jzus.A1600407

CLC number: TU471.7

\section{Introduction}

In China, $53.5 \%$ of the land area is covered by seasonal frozen soil. Under the influence of negative temperatures during winter, pore water in the top soil layer freezes with volume expansion, at the same time, water migrates upward and freezes, causing even greater frost heave. The total frost heave can be as much as 10-30 cm, or even $40 \mathrm{~cm}$. Structures can rarely endure such great deformation (Andersland and Ladanyi, 2004).

\footnotetext{
${ }^{\ddagger}$ Corresponding author

* Project supported by the National Natural Science Foundation of China (No. 51378057), the National Basic Research Program (973 Program) of China (No. 2012CB026104), and the Fund of the North China Power Engineering Co., Ltd. of China Power Engineering Consulting Group (No. C14L01530), China

(DD ORCID: Teng-fei WANG, http://orcid.org/0000-0003-4079-0687

(C) Zhejiang University and Springer-Verlag Berlin Heidelberg 2016
}

Solar photovoltaic power generation is a new green energy industry, and the light-rich regions are widely distributed in seasonal frozen regions where solar power is sufficient. Compared with other loads, the weight of photovoltaic panels is smaller, which results in the decrease in generating efficiency or even total failure, due to uneven frost heave.

Screw pile (Fig. 1) has been widely used in the engineering field on the basis of being environmentally-friendly, having ease of construction and ease of transport. Papadopoulou et al. (2014) analyzed the response of screw micropiles subjected to axial and horizontal loading by the finite element method and investigated its full scale in situ tests. A prebored screw pile method is proposed that piles are constructed by the rotary penetration of a screw pile into a prebored hole filled with some cement milk and the diameter of the hole is then smaller than that of the screw pile (Lee et al., 2016). Through a comprehensive 
collation of all relevant literature regarding the design of screw piles, Mohajerani et al. (2016) made comparisons and drew relationships which will be ultimately relevant to future efforts associated with the design of screw piles. High strain dynamic tests and full scale static pile loading tests were performed for helical piles to evaluate their static bearing capacity (Sakr, 2013). Mendoza et al. (2015) discussed the behavior of standard groups and piled rafts constructed with helical screw piles found in the typical soil of the Federal District of Brazil; an experimental study was conducted to evaluate the seismic performance of foundations supported by helical piles (El Naggar et al., 2007). Dong et al. (2008; 2009) conducted pullout tests of screw piles to measure load-displacement curves and compared 3 RDDs (the ratio of the laminas distance to the net radius of lamina) in tests to measure their effects.

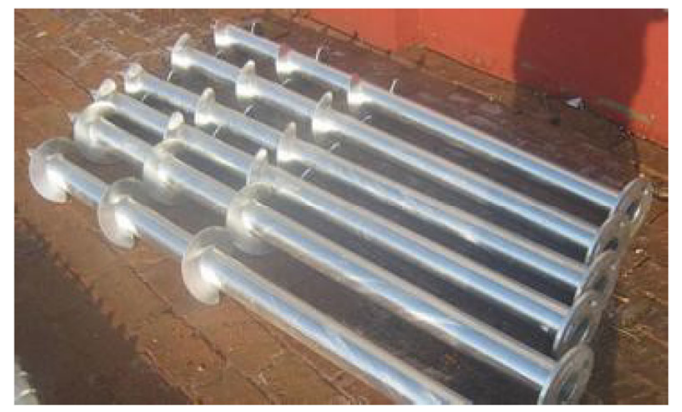

Fig. 1 Screw piles on site

Studies on piles in seasonal frozen regions have been carried out for many years. Gu et al. (2016) studied material parameters critical to lateral response of piles embedded in the frozen ground and ranked their relative importance. A new type of concrete pile, which was carved with grooves refilled with largegrained porous materials, was introduced in QinghaiTibet plateau ( $\mathrm{Li}$ and $\mathrm{Xu}, 2008$ ). Free response of frozen soil-pile interaction was adopted for system identification, which provided a fast way to estimate nonlinearity and approximate modes (Chen et al., 2012). Crowther (2013) presented a design approach to analyze the influence of lateral loads on piles embedded in a layered frozen soil profile. By comparing and analyzing the current studies on frozen zones, a set of model test systems for dynamic frozen soil-pile interactions were developed by Li et al. (2012). The physical pattern of the interactions between boring piles and frozen soil was examined through laboratory tests and field tests (Aksenov et al., 2014). A simplified model related to the vertical vibration of piles was established to analyze the effect of frost and thaw on the complex stiffness (Li et al., 2006). Two theoretical models of piles in seasonal frozen areas were established based on temperature and activelayer thickness (Tang et al., 2015). However, few studies can be found on the combined effects of the screw pile and freeze-thaw cycling. What is more, the studies on screw piles designed for photovoltaic stents which bear light loads is not enough, either. Further study on screw piles of photovoltaic stents in seasonal frozen regions is needed. The laboratory modeling of screw piles simulating practical working conditions is presented in this paper, the effects of different screw piles are compared, and the effects of soil types and some other factors influencing frost heave are summarized.

\section{Experimental scheme}

Experiments on the freezing process of screw piles were conducted for picking the optimal type.

\subsection{Tested soil properties}

This experiment included two different types of soil samples: soil from construction sites of $20 \mathrm{MWp}$ photovoltaic projects located in Wengongwula, Xianghuang Banner, Xilinguole league (marked sample A); Qinghai-Tibet Plateau clay used as a contrast (marked sample B).

Fig. 2 shows the grading curves of the two samples.

According to the standard for soil test method (CSBTS, 1999), sample A is defined as clayey sand (plastic limit $\omega_{\mathrm{p}}=7.9 \%$, liquid limit $\omega_{\mathrm{L}}=25.2 \%$, plasticity index $I_{\mathrm{p}}=17.3 \%$ ) while sample $\mathrm{B}$ is defined as silty clay $\left(\omega_{\mathrm{p}}=20.1 \%, \omega_{\mathrm{L}}=30.7 \%, I_{\mathrm{p}}=10.6 \%\right)$. The basic properties of these two soil samples are summarized in Table 1.

\subsection{Frost heave test of the soil}

In the freezing test, two kinds of water contents (14\% and $18 \%$ ) were selected, and soil sample A was frozen uniaxially for $48 \mathrm{~h}$ to measure the frost heave rate. The system was closed without applying a water supplement. The compactness was 0.93 . 


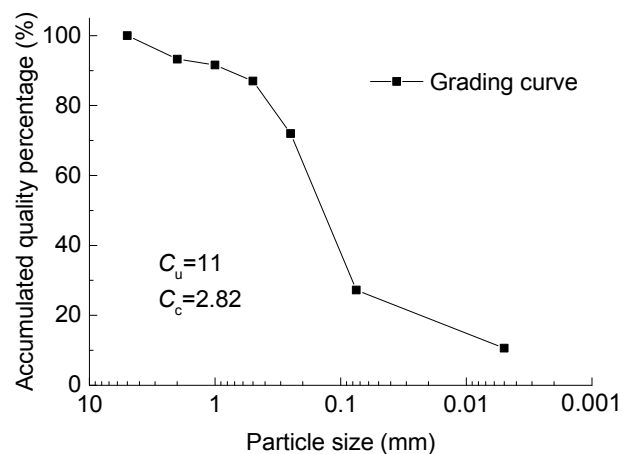

(a)

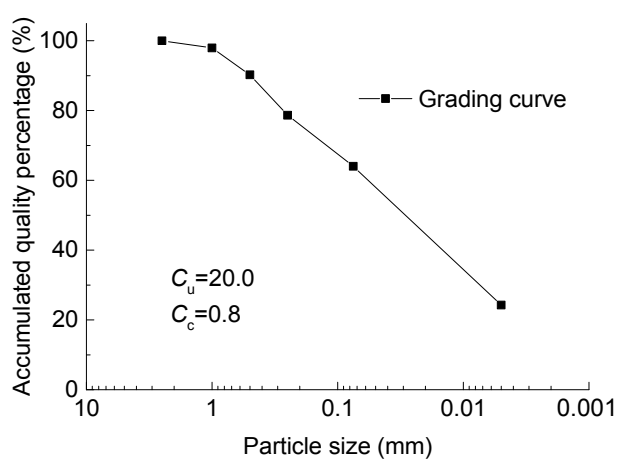

(b)

Fig. 2 Grading curves of the samples $A$ (a) and B (b) $C_{\mathrm{u}}$ : uniformity coefficient; $C_{\mathrm{c}}$ : curvature coefficient

Table 1 Basic soil properties

\begin{tabular}{lcc}
\hline \multirow{2}{*}{ Parameter } & \multicolumn{2}{c}{ Description } \\
\cline { 2 - 3 } & Sample A & Sample B \\
\hline Natural water content $(\%)$ & 2.365 & 3.100 \\
Optimum water content $(\%)$ & 11.0 & 13.2 \\
Maximum dry density $\left(\mathrm{g} / \mathrm{cm}^{3}\right)$ & 1.77 & 1.88 \\
Freezing temperature $\left({ }^{\circ} \mathrm{C}\right)$ & -0.1 & -0.1 \\
Gradation & Well & Poor \\
\hline
\end{tabular}

The soil samples were first placed in a room with a constant temperature of $1{ }^{\circ} \mathrm{C}$. Meanwhile, the temperatures of the upper and bottom cooling bath board (Fig. 3, it provides boundary conditions with negative temperatures) were set as $1{ }^{\circ} \mathrm{C}$ for $12 \mathrm{~h}$, so that the water was evenly distributed and the integral temperature of soil reached $1{ }^{\circ} \mathrm{C}$.

Then temperature of the upper cooling bath board was changed to $-5{ }^{\circ} \mathrm{C}$ with the bottom remaining constant. Temperature and displacement were collected throughout the test, which lasted for $48 \mathrm{~h}$.
According to the temperature-time curve (Fig. 4), the surface temperature of the soil with the water content of $14 \%$ dropped faster than the one with the water content of $18 \%$ and remained constant after $20 \mathrm{~h}$. The temperature of the soil $5 \mathrm{~cm}$ below the surface changed little with water content.

Based on the final temperature distribution, the freezing depths were 14.9 and $14.1 \mathrm{~cm}$ for the soils with the water contents of $18 \%$ and $14 \%$, respectively.
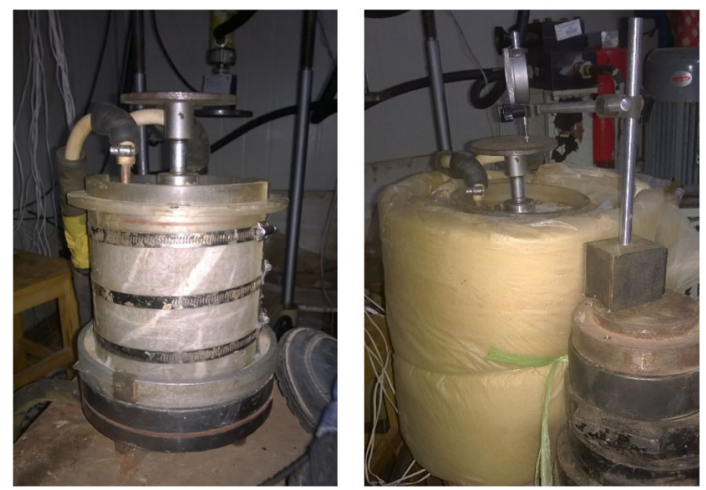

Fig. 3 Frost heave test equipment

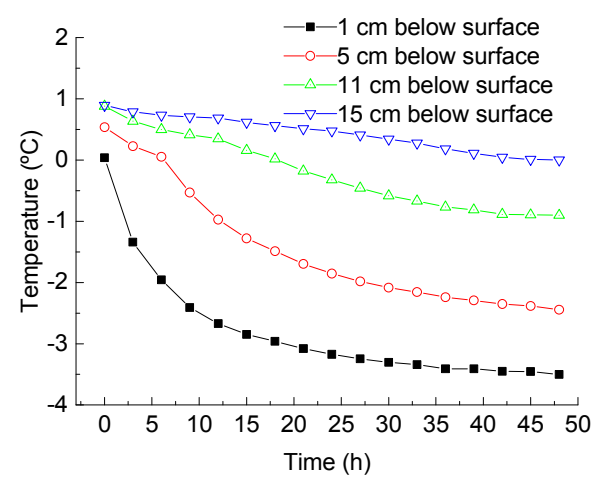

(a)

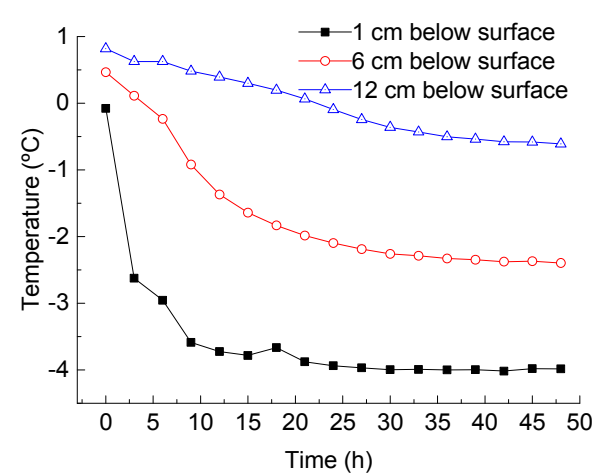

(b)

Fig. 4 Temperatures of different depths varying with time (a) Water content of $18 \%$; (b) Water content of $14 \%$ 
The soil sample with a higher water content showed a larger displacement (Fig. 5), reaching $1.25 \mathrm{~mm}$ at the end of the test, while the soil sample with a lower water content reached a plateau $(0.58 \mathrm{~mm})$ after $24 \mathrm{~h}$.

The frost heave rate is defined as

$$
\eta=\frac{\Delta h}{H_{\mathrm{f}}} \times 100 \%,
$$

where $\eta$ is the frost heave rate, $\Delta h$ is the total frost heave amount, and $H_{\mathrm{f}}$ is the frost depth.

The frost heave rates were $0.83 \%$ and $0.41 \%$ for the soils with the water contents of $18 \%$ and $14 \%$, respectively. When the water content increases from $14 \%$ to $18 \%$, the frost heave rate almost doubled for sample A. This can be explained by the fact that more water migrates to a freezing front, leading to a greater frost heave amount. To show the jacking-up of piles more significantly, water content of $18 \%$ was adopted in the later test.

For sample B under the same condition, the frost heave rate was $1.6 \%$ (water content of $18 \%$ ).

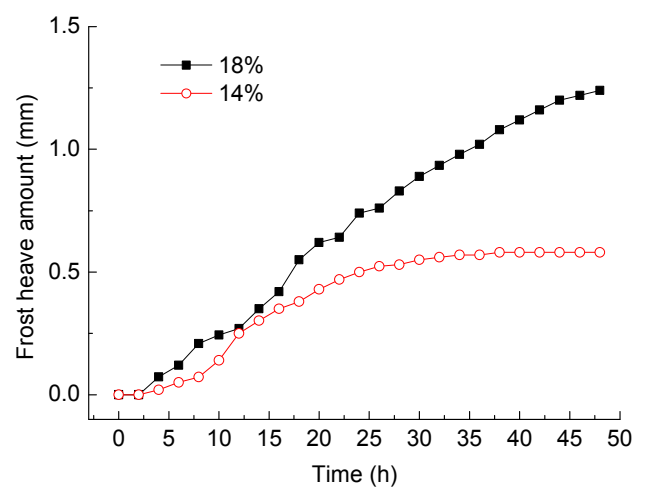

Fig. 5 Frost heave varying with time

\subsection{Similarity principle}

To limit size, the model test (scaling-down) was adopted to simulate practical working conditions. First, some hypotheses were proposed:

1. Ignore internal thermal resistance, which means the soil temperature is dependent on time $\tau$, and independent of space coordinates.

2. Under practical working conditions, the influence scope around the pile is a square whose side length is $1.2 \mathrm{~m}$. Energy released from the ice-water phase transition is defined as the inner heat source.
Based on the hypotheses above, the conduction differential equation with an inner heat source is simplified as

$$
\frac{\partial t}{\partial \tau}=\frac{\dot{\Phi}}{\rho c}
$$

where $t$ is the temperature, $\rho$ and $c$ are the density and heat capacity, respectively, and $\Phi$ is the inner heat source.

The heat conservation formula of the boundary heat transfer is

$$
\dot{\Phi} V=-A h \theta
$$

where $V$ is the volume, $A$ is the contact area, $h$ is the surface coefficient of heat transfer, and $\theta$ is the excess temperature.

Combine Eqs. (2) and (3), we can obtain

$$
\rho c V \frac{\partial \theta}{\partial \tau}=-h A \theta
$$

Applying the integration by parts, Eq. (5) can be given:

$$
\frac{h A}{\rho c V} \tau=\frac{h}{\lambda} \times \frac{\alpha \tau}{l},
$$

where $\lambda$ is the thermal conductivity, $\alpha=\lambda /(\rho c)$ is a constant, and $l=V / A$ is the characteristic length, representing the height of the soil sample.

To simulate the practical working condition, Eq. (6) should be satisfied:

$$
\left(\frac{h_{1}}{\lambda} \times \frac{\alpha \tau_{1}}{l_{1}}\right):\left(\frac{h_{2}}{\lambda} \times \frac{\alpha \tau_{2}}{l_{2}}\right)=1
$$

where subscripts 1 and 2 represent practical working condition and test, respectively.

To guarantee the similarity of heat convection, the Nusselt number $N u=h d / \lambda_{\text {a }}$ should be the same, where $d$ is the characteristic length, representing the side length of the square of the heat convection, and $\lambda_{\mathrm{a}}$ is the thermal conductivity of the air.

In the model test, the side length of the influence scope square is $0.4 \mathrm{~m}$. According to the geometry similarity ratio $C_{\mathrm{G}}=1.2 / 0.4=3$, then we get the 
similarity ratio of the surface coefficient of the heat transfer $C_{\mathrm{h}}=1 / 3$. The embedment length of the screw pile is $1.8 \mathrm{~m}$ under practical working conditions, while the model pile is $0.6 \mathrm{~m}$, the similarity ratio of $l$ is $C_{l}=1.8 / 0.6=3$, so according to Eq. (6), the similarity coefficient of time is $C_{\tau}=9$.

In the freezing test, the same effect of the freezing condition is available as long as the similarity ratio of the freezing index is $C_{\mathrm{f} \tau}=C_{\tau}=9$, the duration of the freezing in seasonal frozen regions simulated is $180 \mathrm{~d}$, and the average temperature is $-5.3^{\circ} \mathrm{C}$. Thus, the test time can be reduced to $7 \mathrm{~d}$ if we reduce the temperature of the upper cooling bath board (Table 2).

\subsection{Jacking-up test of piles}

The main instrument adopted in the test was the multifunctional model test box (Fig. 6, size: $1000 \mathrm{~mm}$ $\times 1000 \mathrm{~mm} \times 400 \mathrm{~mm}$ ), on top of which the cooling bath board was connected with the circulator. Using this approach, the stable temperature field was formed inside the soil samples, which could simulate practical working conditions. Each pile hole on top of the box matches one model pile.

Then, six types of model piles and the corresponding basic properties are listed in Fig. 7 and Table 3 .
Three same types of piles were tested in each group (Table 4), types of piles were changed in the
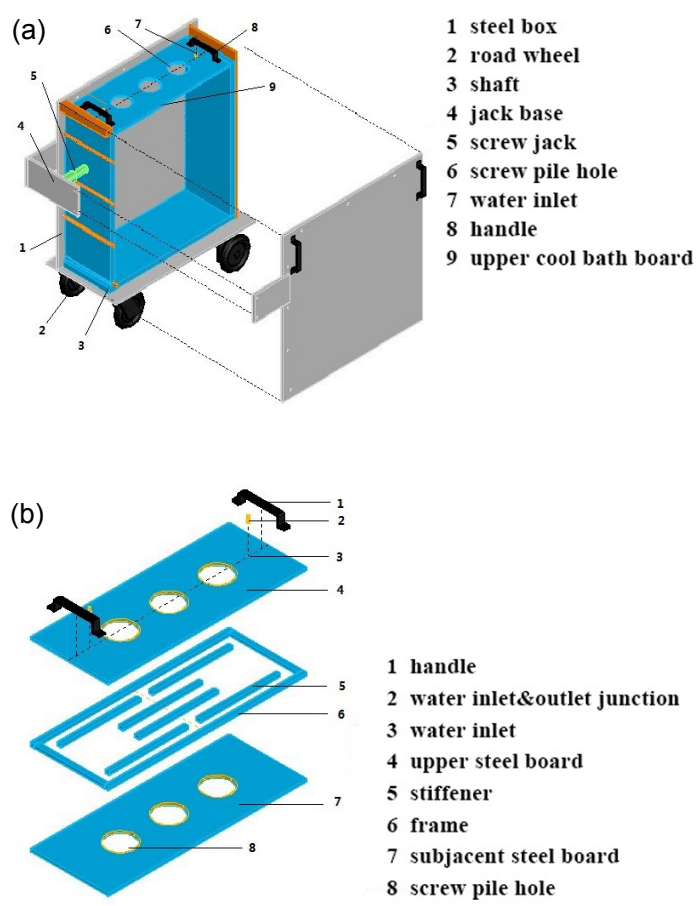

Fig. 6 Multifunctional model test box (a) and its upper board (b)

Table 2 Test conditions set by similarity principle

\begin{tabular}{lccccc}
\hline \multicolumn{1}{c}{ Condition } & $\begin{array}{c}\text { Side length of } \\
\text { square }(\mathrm{m})\end{array}$ & $\begin{array}{c}\text { Embedment } \\
\text { length }(\mathrm{m})\end{array}$ & $\begin{array}{c}\text { Freezing index } \\
\left({ }^{\circ} \mathrm{C} \cdot \mathrm{d}\right)\end{array}$ & $\begin{array}{c}\text { Duration } \\
(\mathrm{d})\end{array}$ & $\begin{array}{c}\text { Boundary } \\
\text { temperature }\left({ }^{\circ} \mathrm{C}\right)\end{array}$ \\
\hline Simulated condition & 1.2 & 1.8 & 954 & 180 & -5.3 \\
Model condition & 0.4 & 0.6 & 105 & 7 & -15.0 \\
\hline Similarity ratio & 3 & 3 & 9 & - & - \\
\hline
\end{tabular}

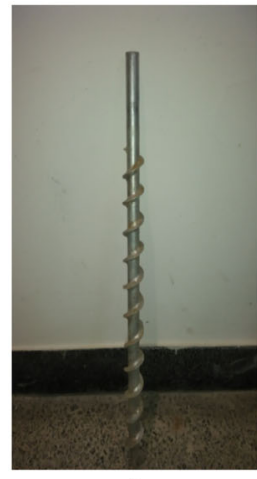

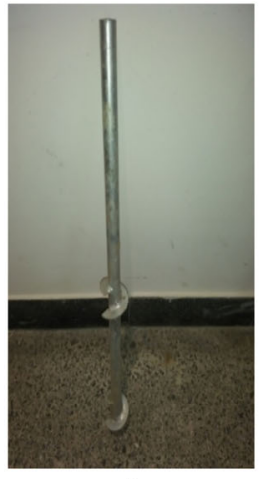

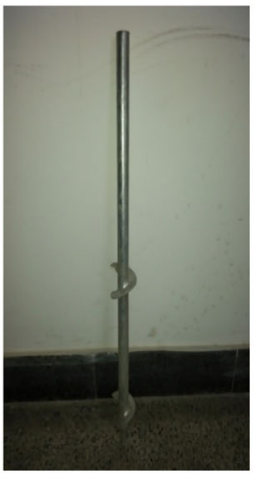

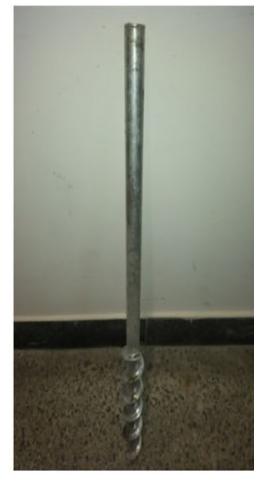

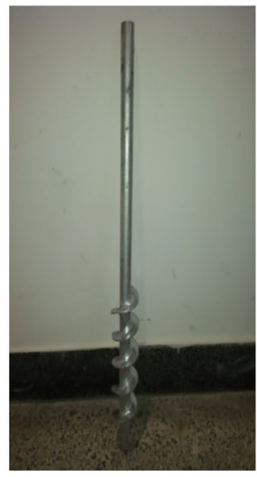

5

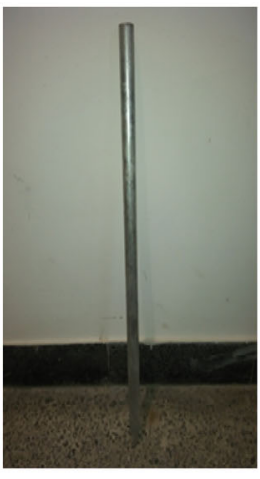

Fig. 7 Six types of model piles

1: all-bladed pile; 2: large-double-blade pile; 3: small-double-blade pile; 4: small-half-bladed pile; 5: large-half-bladed pile; 6: smooth pile 
first six groups, and then, sample B was tested in the last two groups. As the weight of the photovoltaic stents is relatively small, there was not any load applied to the top.

Experimental procedures were as follows:

(a) Preparation. Prepare soil sample with predetermined water content, and make sure all sensors are under good conditions.

(b) Installation and compaction procedure. Fill the soil into the box from the top, until it reaches the height of the sensor (Fig. 8), and then compact by vibrating. In order to reach target compactness, the drop hammer height and times of compactness are controlled (Fig. 9). The depth of each layer is $0.15 \mathrm{~m}$. The model pile is also embedded inside in this process. Especially, for each layer, the compacted soil around the pile is $2-3 \mathrm{~cm}$ higher than the rest (compact in lateral and vertical directions). This is to ensure occlusion between soil and pile. Check the vertical degree before paving the next layer. When the target height of the soil is satisfied, level the surface, and fasten the bolts of the fastener screw.

To simplify, the measuring points of different depths were marked with specific names, e.g., P15 represented the soil $15 \mathrm{~cm}$ below the surface. (c) Refrigeration and monitor. Connect liquid inlet and outlet of the cooling bath circulator to the upper board of the test box. Before placing the upper board on top of the soil, check the flatness of the soil surface. Make the leak detection for the cooling bath board. The initial temperature of the soil is $15^{\circ} \mathrm{C}$. Set the temperature of the upper board as $-15^{\circ} \mathrm{C}$ (Fig. 10). Data was collected using DataTaker DT80 (Thermo Fisher, Australia) in this process (Figs. 11 and 12). The test lasts $7 \mathrm{~d}$.

(d) Thawing and soil unloading. After the freezing process, change the temperature of the cooling

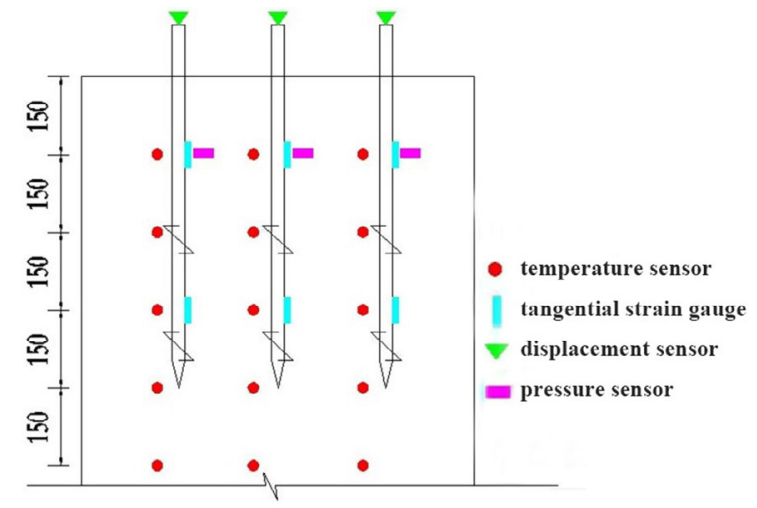

Fig. 8 Layout of sensors (unit: mm)

Table 3 Basic properties of piles

\begin{tabular}{lccccccc}
\hline \multicolumn{1}{c}{ Physical property } & No. & $\begin{array}{c}\text { Pitch } \\
(\mathrm{mm})\end{array}$ & $\begin{array}{c}\text { Diameter } \\
(\mathrm{mm})\end{array}$ & $\begin{array}{c}\text { Blade thick- } \\
\text { ness }(\mathrm{mm})\end{array}$ & $\begin{array}{c}\text { Blade width } \\
(\mathrm{mm})\end{array}$ & $\begin{array}{c}\text { Blade } \\
\operatorname{dip}\left({ }^{\circ}\right)\end{array}$ & $\begin{array}{c}\text { Length } \\
(\mathrm{mm})\end{array}$ \\
\hline & 1 & 54 & 59 & 2 & 10 & 30 & 700 \\
Density: $7.85 \mathrm{~g} / \mathrm{cm}^{3} ;$ & 2 & 170 & 79 & 2 & 27 & 30 & 700 \\
elastic modulus: $202 \mathrm{GPa} ;$ & 3 & 206 & 59 & 2 & 17 & 30 & 700 \\
shear strength: $310-380 \mathrm{MPa} ;$ & 4 & 54 & 59 & 2 & 17 & 30 & 700 \\
tensile strength: $440-470 \mathrm{MPa} ;$ & 5 & 54 & 79 & 2 & 27 & 30 & 700 \\
$\lambda: 52.34 \mathrm{~W} /(\mathrm{m} \cdot \mathrm{K})$ & 6 & - & 59 & - & - & - & 700 \\
\hline
\end{tabular}

Table 4 Test condition and test scheme

\begin{tabular}{lccc}
\hline \multicolumn{1}{c}{ Test condition } & No. & Type of piles & Soil sample \\
\hline & 1 & All-bladed pile & \\
Compactness: $0.93^{*} ;$ & 2 & Large-double-blade pile & \\
water content: $18 \% ;$ & 3 & Small-double-blade pile & Sample A \\
initial temperature: $15^{\circ} \mathrm{C} ;$ & 4 & Small-half-bladed pile & \\
temperature of upper cooling bath & 5 & Large-half-bladed pile & \\
board: $-15^{\circ} \mathrm{C}$; & 6 & Smooth pile & \\
duration: $7 \mathrm{~d}$ & 7 & Small-double-blade pile & Sample B \\
\cline { 2 - 4 } & 8 & Large-half-bladed pile & \\
\hline
\end{tabular}

${ }^{*}$ The value is obtained from the $i n-$ situ undisturbed soil 
bath to $15{ }^{\circ} \mathrm{C}$ to melt the frozen soil. When the integral temperature of the soil exceeds $0{ }^{\circ} \mathrm{C}$, open the front board, and unload the soil with a shovel. Check the condition of each sensor, pave and dry the soil.

(e) Repetitive experiments. Change test condition, repeat procedures (a)-(d) for seven more times.

\section{Results and discussion}

To avoid confusion with different temperature reference points, all the temperatures mentioned below in degree Celsius $\left({ }^{\circ} \mathrm{C}\right)$ are measured from the

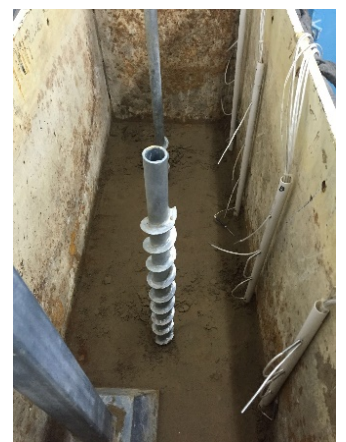

Fig. 9 Piles, temperature sensors, and hammer

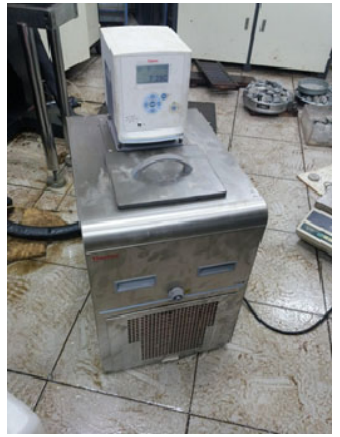

Fig. 10 Cooling bath
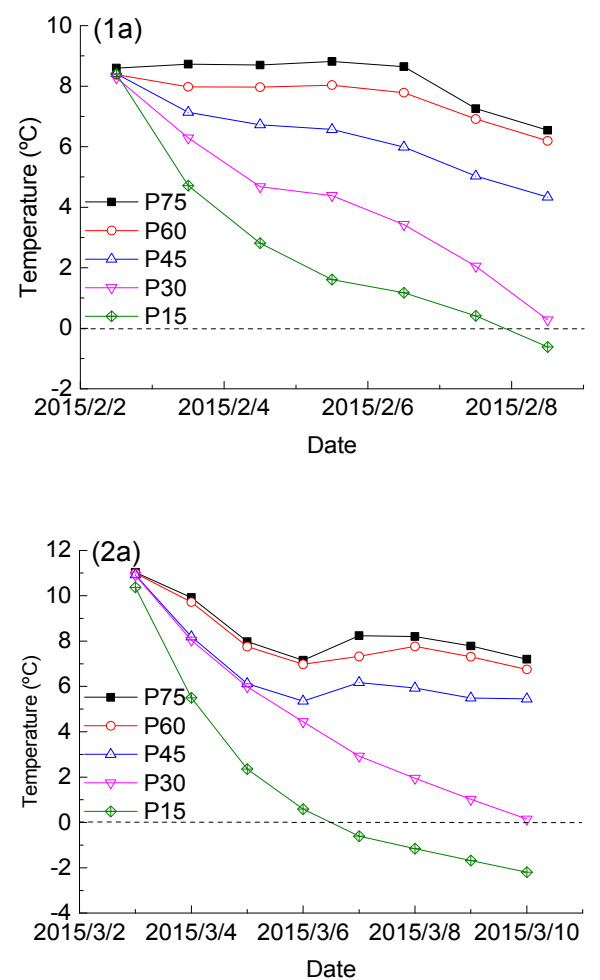

absolute temperature of $273 \mathrm{~K}$. Temperature sensors were placed at five depths. The adopted value was the average temperature of the three piles.

There were considerable differences in the trends of temperature for the different depths (Fig. 13, left column). For the first three groups, the temperature of P30 decreased steadily, until it hit the lowest point which was around $0{ }^{\circ} \mathrm{C}$; for the rest of the three groups, a fall was observed in the first 3-4 d, after which the temperature remained stable at around $0{ }^{\circ} \mathrm{C}$, apart from slight fluctuations. The results verified that the freezing depth reached $30 \mathrm{~cm}$ based on the freezing temperatures obtained.

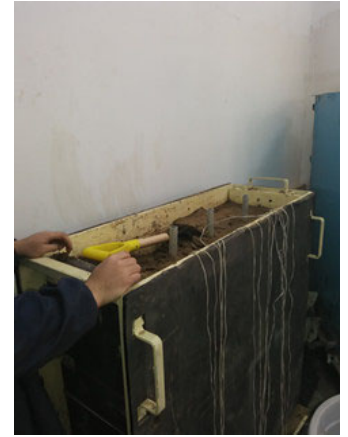

Fig. 11 Test box in progress

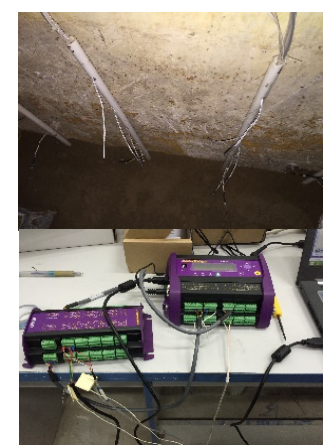

Fig. 12 Temperature sensors and DT80
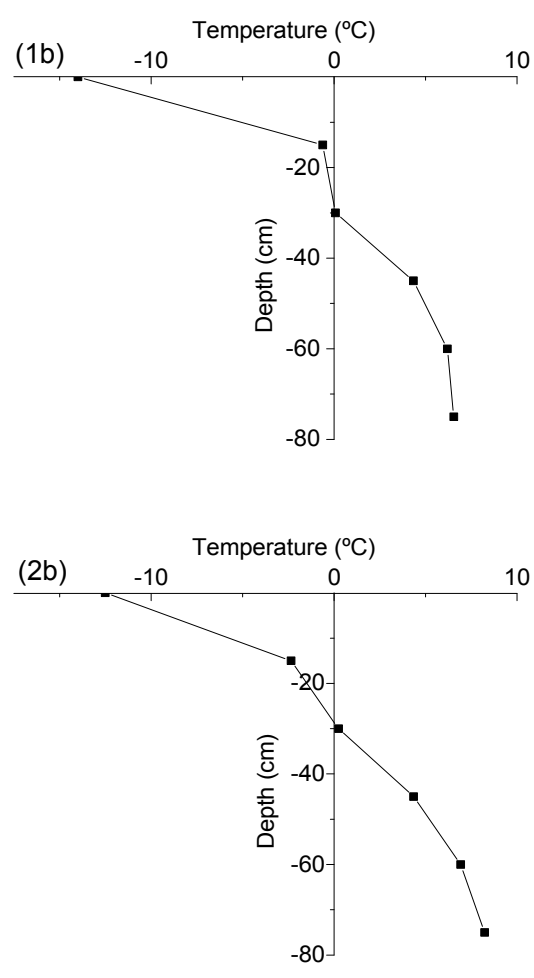

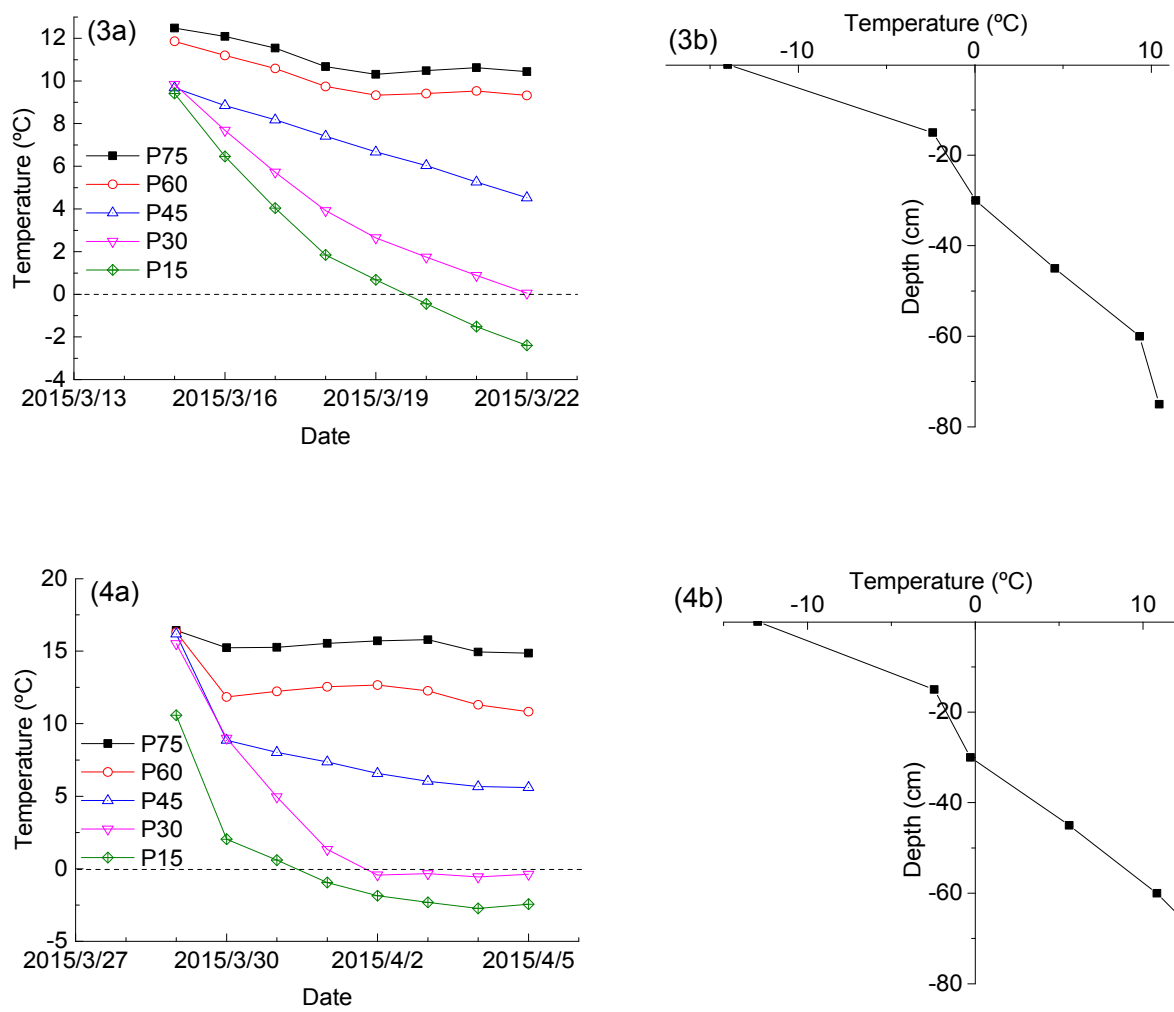

(4b)
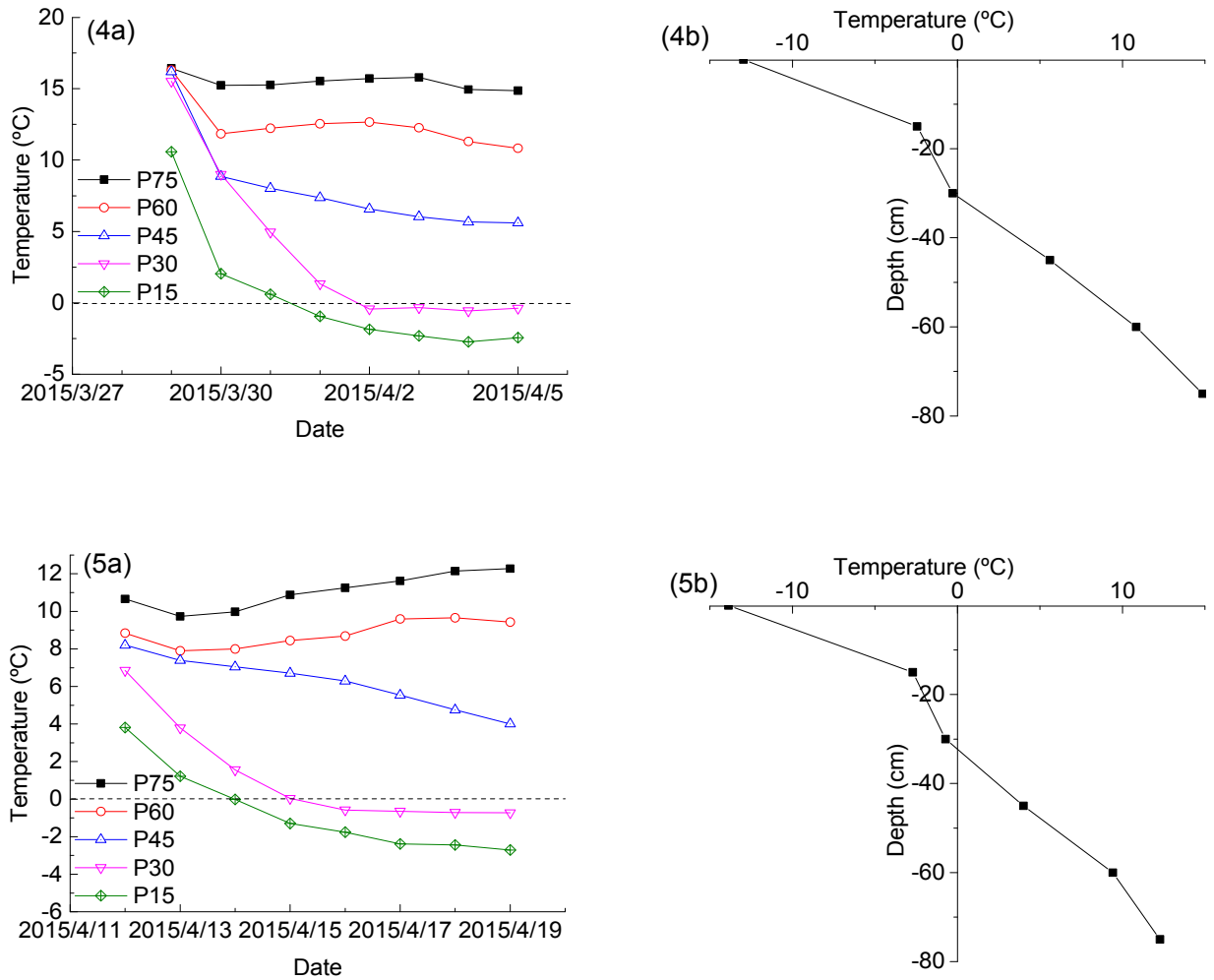

(5b)
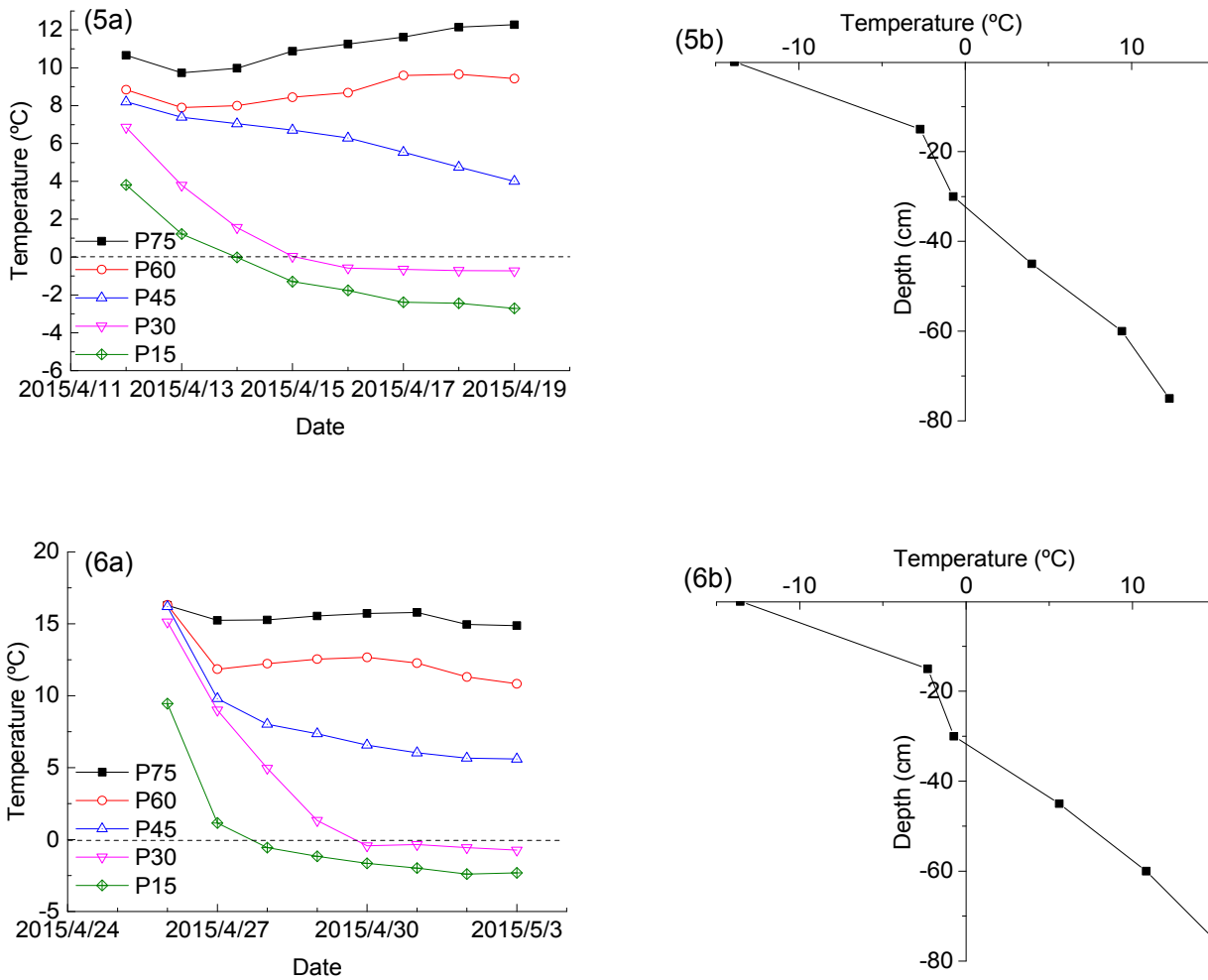

(6b)

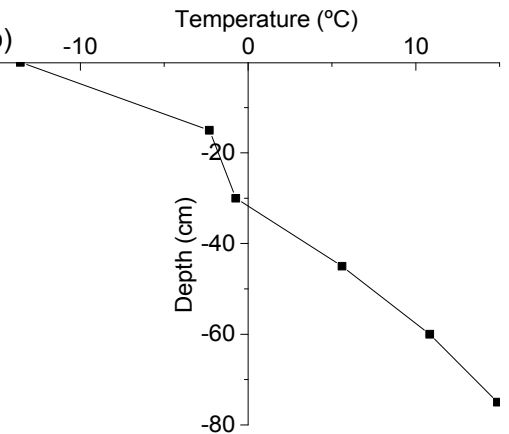

Fig. 13 Temperature varying with time and final temperature varying with depth a: temperature varying with time; b: final temperature varying with depth; $1-6$ : group numbers 
Temperatures that ranged from $\mathrm{P} 45$ to $\mathrm{P} 75$ declined slowly with many obvious fluctuations (especially for groups 2 and 5). The temperature of P75 even showed an upward trend during certain periods in some of the groups. It indicated that the cooling bath had little effect on the soil around the pile toe. The temperature of soil P15 dropped sharply to around $-2.5{ }^{\circ} \mathrm{C}$ at the end of the test. The surface temperature ranged from $-12{ }^{\circ} \mathrm{C}$ to $-14{ }^{\circ} \mathrm{C}$.

The relationship between the final temperature and depth is shown in Fig. 13 (right column), the boundary condition greatly affected the soil within a depth of $15 \mathrm{~cm}$, but the temperature was closer to the initial value as the depth increased.

The displacement of each pile was measured by sensors on top of the pile. Then the average jackingup displacement was calculated (Fig. 14). According to the results, the piles of test groups 2-4 did not jack up initially, for example, group 2 with a large-doubleblade pile did not see a surge before $120 \mathrm{~h}$. This was because the initial jacking-up force induced by the frost heave of the soil was smaller than the anchorage force. The non-jacking-up duration became longer as the number or size of the helical blades, which were in the unfrozen layer, increased. Group 4 with a largehalf-bladed pile began to rise after $50 \mathrm{~h}$. Unlike the other five groups, the jacking-up displacement of group 6 with smooth pile increased linearly with time to about $3 \mathrm{~mm}$ measured from the beginning. This reflected the role of helical blades which played an important part in anchoring. The dispersion of the data in groups 1,2 , and 5 were partially due to a slight irregularity in the surface of the soil and freezing rate.

Soil sample B, which was more likely to frost heave, was adopted in groups 7 and 8 . Unlike groups 3 and 5 (same screw piles were adopted), the screw piles began to jack up from the beginning. Jacking-up displacement saw a steady growth during $7 \mathrm{~d}$. Placing the pile in the soil which was more susceptible to frost heave can induce a much larger jacking-up displacement. It is very necessary to point out that the upward trend still existed when the test ended, which was definitely related to the frost depth.

The average displacement at the end of the test is summarized in Table 5 (p.522). The reduction coefficient $C_{\mathrm{r}}$ was defined as

$$
C_{\mathrm{r}}=\frac{\Delta h_{\mathrm{i}}}{\Delta h_{\text {smooth }}},
$$

where $\Delta h_{\mathrm{i}}$ and $\Delta h_{\text {smooth }}$ represent the jacking-up displacement of the screw piles and smooth pile, respectively.

According to the value of $C_{\mathrm{r}}$, the helical blade in the unfrozen layer can reduce the jacking-up displacement by $32 \%-97 \%$.

The size relationship of displacement can be listed as: large-double-blade pile $<$ large-half-bladed pile $<$ small-half-bladed pile $<$ small-double-blade pile $<$ all-bladed pile $<$ smooth pile. It indicates that the large-double-blade pile performed the best in the anti-jacking-up.

Take group 2 (large-double-blade pile) for example. The jacking-up displacement was closely related to the freezing depth. According to Figs. 13 and 14, the relationship between the jacking-up displacement and freezing depth is summarized in Fig. 15 (p.522). The threshold of the freezing depth for a large-double-blade pile is $20 \mathrm{~cm}$ (jacking-up displacement began to rise from this point).

The fitting formula is given as

$$
h=-0.148+7.64 \times 10^{-4} z,
$$

where $z$ and $h$ represent the freezing depth $(\mathrm{mm})$ and jacking-up displacement $(\mathrm{mm})$, respectively.

In a similar way, the linear relationships of the rest groups are obtained (Table 6, p.522).

The value of $b$ represents the sensitivity of the jacking-up displacement to freezing depth. It proves the anti-jacking-up ability which was obtained from Table 5 in another aspect. Given certain values of the freezing depth, the jacking-up displacement of the screw piles could be obtained.

A large-blade pile was generally better than a small-blade pile considering that a larger blade with a larger area of thrust surface could resist more tangential frost heave forces. However, a large-halfbladed pile was not the optimal one. This can be explained by the fact that when the ratio of the screw thread spacing to blade width was relatively small, the screws acted like a smooth pile with a large diameter, which affected the anti-jacking-up ability in return. The screw blade of the all-bladed pile which was in the unfrozen soil could anchor the pile, while the 

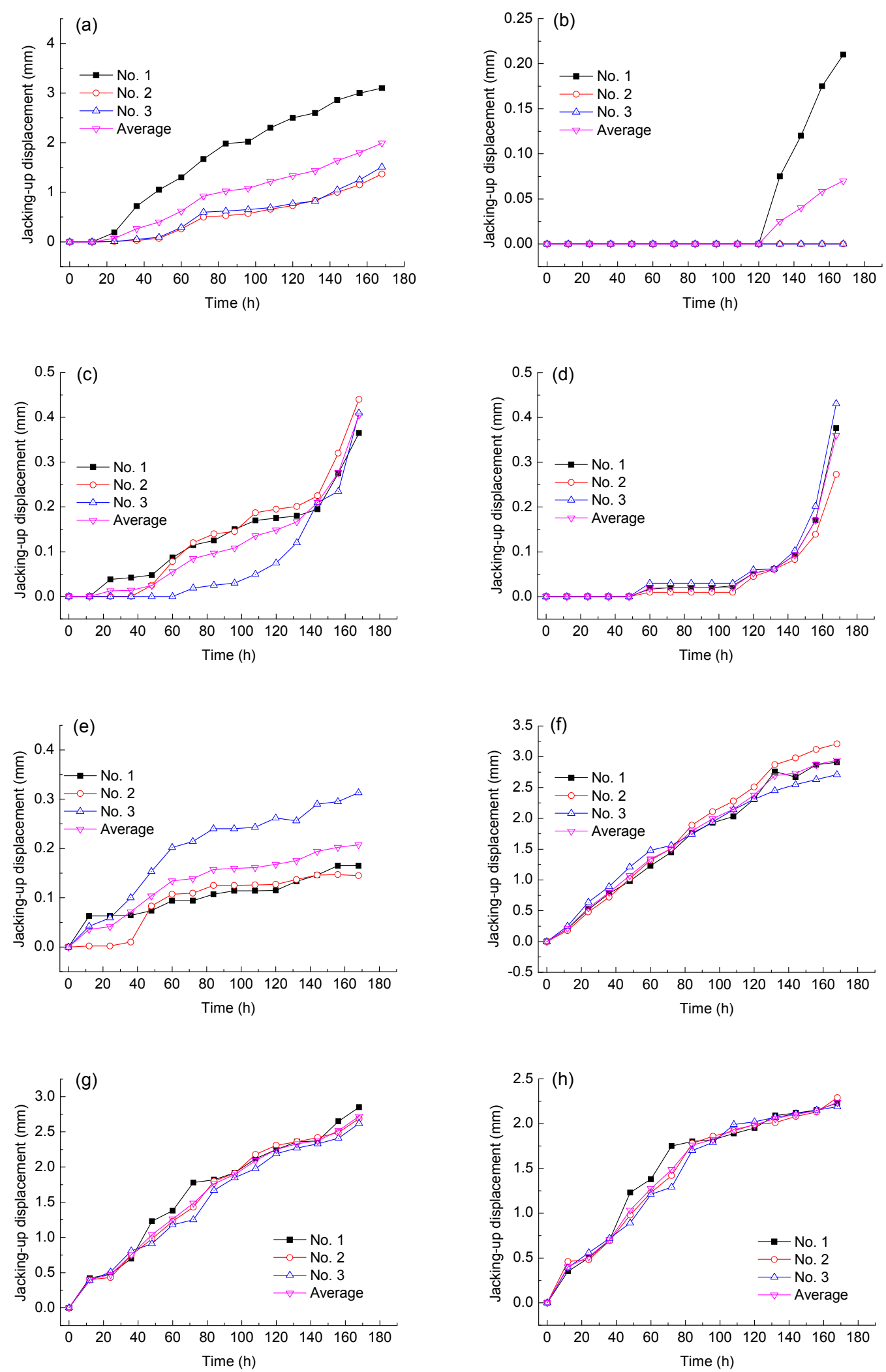

Fig. 14 Jacking-up displacement varying with time

Nos. 1, 2, and 3 represent three piles in the same group; average line represents the average value of the three piles; (a)-(h) represent the test groups $1-8$, respectively 
Table 5 Final jacking-up displacement of piles

\begin{tabular}{ccccccc}
\hline \multirow{2}{*}{ Type } & \multicolumn{5}{c}{ Jacking-up displacement $(\mathrm{mm})$} \\
\cline { 2 - 7 } & All-bladed & Large-double-blade & Small-double-blade & Small-half-bladed & Large-half-bladed & Smooth pile \\
\hline Sample A & 1.982 & 0.070 & 0.413 & 0.352 & 0.208 & 2.943 \\
Sample B & & & 2.72 & & 2.18 & \\
\hline$C_{\mathrm{r}}$ & $67.35 \%$ & $2.38 \%$ & $28.08 \%$ & $11.96 \%$ & $7.07 \%$ & - \\
\hline
\end{tabular}

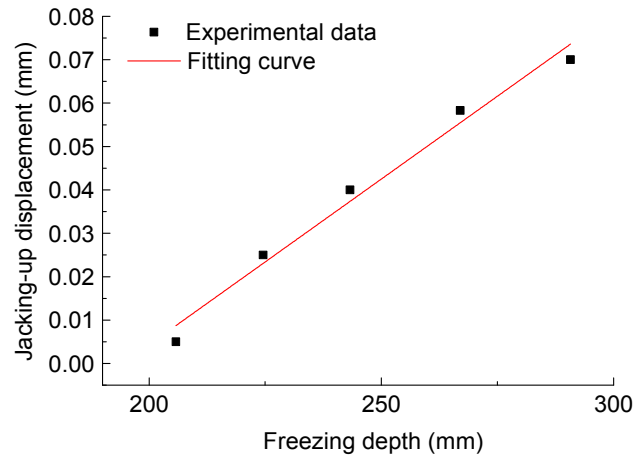

Fig. 15 Jacking-up displacement varying with freezing depth

Freezing depth was obtained by interpolation based on Fig. 13-2a and the freezing temperature of the soil; jacking-up displacement is obtained from Fig. 14b

Table 6 Fitting coefficients of jacking-up displacement vs. freezing depth

\begin{tabular}{ccc}
\hline No. & Coefficient $a$ & Coefficient $b$ \\
\hline 1 & 1.194 & $2.90 \times 10^{-3}$ \\
2 & -0.148 & $7.64 \times 10^{-4}$ \\
3 & 0.036 & $6.83 \times 10^{-4}$ \\
4 & 0.186 & $9.52 \times 10^{-4}$ \\
5 & 0.038 & $9.00 \times 10^{-4}$ \\
6 & 1.007 & $1.47 \times 10^{-2}$ \\
\hline
\end{tabular}

Note: fitting formula is $h=a+b z$

screw blade in the frozen soil could aggravate the jacking-up process (Fig. 16).

Groups 7 and 8 demonstrated that the same pattern occurred in soil sample B. But the displacement was much larger due to the soil character.

A pressure sensor was placed $15 \mathrm{~cm}$ below the surface to measure soil pressure. Only the results of group 6 are listed (Fig. 17) here, as all six groups shared similar patterns.

The soil pressure reached $140 \mathrm{kPa}$ on the second day, and then fluctuated between 140 and $150 \mathrm{kPa}$. Affected by the negative temperature, the water in the

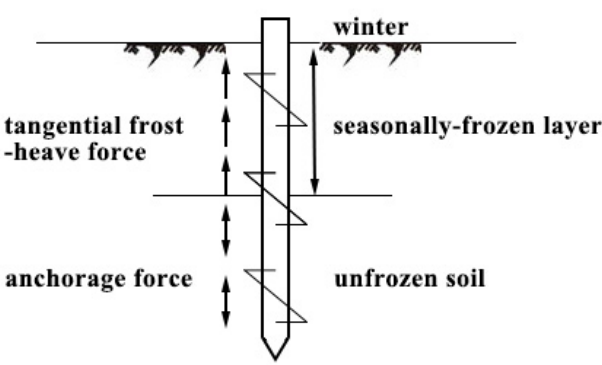

Fig. 16 Schematic diagram of the screw pile

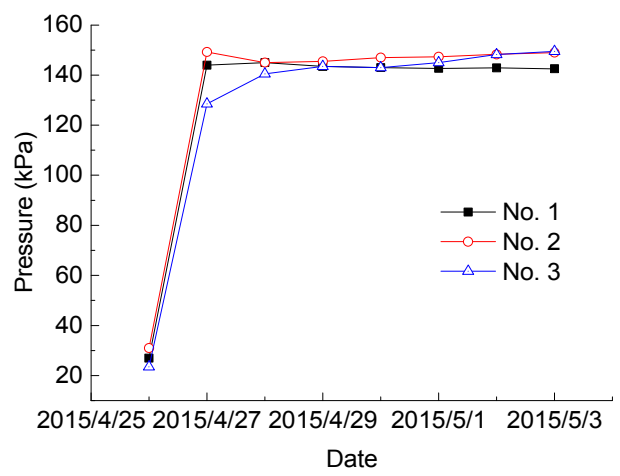

Fig. 17 Soil Pressure varying with time

soil began to freeze, leading to an increase in soil pressure. As there was no water supplement, no obvious changes were found on the following days when the ice content became stable. The soil pressure fluctuated on a small scale when the freezing front developed at a deeper layer.

Studies on piles in seasonal frozen regions have been carried out for many years, but the mechanism of frost heave is still unclear, and studies on piles of photovoltaic stents, which bear light load, is still not enough. The target of this test is to simulate practical working conditions, and compare anti-jacking-up ability of different screw piles. In fact, indoor tests could not totally reflect geological, hydrologic conditions and structures which are found in the field. 
The results of the tangential force which can shed light on the development of the frost heave and pile-soil interface were not satisfying. However, the excellent ability against jacking-up of the largedouble-blade pile was verified in our test. The final displacement was only equal to $2.38 \%$ of that of the smooth pile. In addition, according to the temperature distribution, the layout of the screw blades could be optimized, which provides an important reference to decision-making in the field. In advance, more universal conclusions are to be obtained in various ways, such as applying loads on the top, changing freezing depth, and conducting full-scale test.

\section{Conclusions}

Screw piles of photovoltaic stents in seasonal frozen regions suffer from frost heave problems during winter. Experiments were conducted to pick the optimal piles against jacking-up disease. Based on the test results and analysis above, the following conclusions can be drawn:

1. In the jacking-up test of piles, the displacement of the screw piles was generally smaller than that of the smooth pile, which proved the effectiveness of screw piles in seasonal frozen regions. Note that the same patterns occurred in samples A and B.

2. The results showed that large-double-blade piles could inhibit jacking-up most effectively in seasonal frozen regions where the freezing depth reaches $0.9 \mathrm{~m}$ in winter. Screw blades were also recommended to be deployed in unfrozen regions. According to the results, the jacking-up displacement increasing order is: large-double-blade pile $<$ largehalf-bladed pile $<$ small-half-bladed pile $<$ small-doubleblade pile $<$ all-bladed pile $<$ smooth pile.

3. For each pile, the linear relationship between the jacking-up displacement and freezing depth was obtained. The slope of the fitting line ranged from $6.83 \times 10^{-4}$ to $1.47 \times 10^{-2}$. This could be applied for prediction when the freezing depth is clear.

4. Soil pressure increased greatly when the water in the pore began to freeze, but changed little when the ice content became stable. It indicated that the soil pressure remained stable in the frozen zone during the freezing process.

\section{References}

Aksenov, V.I., Gevorkyan, S.G., Iospa, A.V., et al., 2014. Performance characteristics of boring piles in frozen soils. Soil Mechanics and Foundation Engineering, 51(4):204-211.

http://dx.doi.org/10.1007/s11204-014-9278-4

Andersland, O.B., Ladanyi, B., 2004. Frozen Ground Engineering, 2nd Edition. The American Society of Civil Engineers, John Wiley \& Sons, Inc., USA, p.3-7.

Chen, G.S., Davis, D., Hulsey, J.L., 2012. Measurement of frozen soil-pile dynamic properties: a system identification approach. Cold Regions Science and Technology, 70:98-106.

http://dx.doi.org/10.1016/j.coldregions.2011.08.007

Crowther, G.S., 2013. Frozen soil strength criteria for lateral pile analysis. Journal of Cold Regions Engineering, 27(3): 155-167.

http://dx.doi.org/10.1061/(asce)cr.1943-5495.0000058

CSBTS (China State Bureau of Technical Supervision), 1999. Standard for Soil Test Method, GB/T 50123-1999. China Planning Press, Beijing, China (in Chinese).

Dong, T.W., Liang, L., Wang, W., et al., 2008. Experimental analysis on the lamina-soils interaction in pullout screw pile foundation. Engineering Mechanics, 25(8):150-155 (in Chinese).

Dong, T.W., Liang, L., Huang, L.Z., et al., 2009. Pullout test of screw pile foundation. Rock and Soil Mechanics, 30(1):186-190 (in Chinese). http://dx.doi.org/10.16285/j.rsm.2009.01.043

El Naggar, M.H., Youssef, M.A., Ahmed, M., 2007. Monotonic and cyclic lateral behavior of helical pile specialized connectors. Engineering Structures, 29(10):2635-2640. http://dx.doi.org/10.1016/j.engstruct.2007.01.018

Gu, Q., Yang, Z.H., Peng, Y., 2016. Parameters affecting laterally loaded piles in frozen soils by an efficient sensitivity analysis method. Cold Regions Science and Technology, 121:42-51.

http://dx.doi.org/10.1016/j.coldregions.2015.10.006

Lee, C.W., Kim, Y.S., Park, S.Y., 2016. Development of prebored screw pile method and evaluation of its bearing characteristics. Marine Georesources \& Geotechnology, 34(1):42-56. http://dx.doi.org/10.1080/1064119X.2014.954682

Li, N., Xu, B., 2008. A new type of pile used in frozen soil foundation. Cold Regions Science and Technology, 53(3): 355-368. http://dx.doi.org/10.1016/j.coldregions.2007.10.005

Li, Q., Wang, K.H., Xie, K.H., 2006. Dynamic response of vertically vibrating pile during freezing and thawing. Chinese Journal of Geotechnical Engineering, 28(1): 48-55 (in Chinese).

Li, Y.B., Zhang, H.R., Quan, K.J., 2012. Development of model test system for dynamic frozen soil-pile interaction. Chinese Journal of Geotechnical Engineering, 34(4):774-780 (in Chinese).

Mendoza, C.C., Cunha, R., Lizcano, A., 2015. Mechanical and 
numerical behavior of groups of screw (type) piles founded in a tropical soil of the Midwestern Brazil. Computers and Geotechnics, 67:187-203. http://dx.doi.org/10.1016/j.compgeo.2014.09.010

Mohajerani, A., Bosnjak, D., Bromwich, D., 2016. Analysis and design methods of screw piles: a review. Soils and Foundations, 56(1):115-128. http://dx.doi.org/10.1016/j.sandf.2016.01.009

Papadopoulou, K., Saroglou, H., Papadopoulos, V., 2014. Finite element analyses and experimental investigation of helical micropiles. Geotechnical and Geological Engineering, 32(4):949-963.

http://dx.doi.org/10.1007/s10706-014-9771-6

Sakr, M., 2013. Comparison between high strain dynamic and static load tests of helical piles in cohesive soils. Soil Dynamics and Earthquake Engineering, 54:20-30. http://dx.doi.org/10.1016/j.soildyn.2013.07.010

Tang, L.Y., Yang, G.S., Ye, W.J., 2015. Pile bearing capacity prediction considering air temperature change in cold regions. Chinese Journal of Underground Space and Engineering, 11(3):652-657 (in Chinese).

\section{中文概要}

题 目: 季节性冻土区光伏支架螺旋桩抗冻拔试验研究

目 的：基于相似性原理, 模拟实际工况中的降温冻结过
程; 通过室内试验确定最优桩型, 并推导冻拔量 与冻深的定量关系。

创新点: 1 . 进行季节性冻土区螺旋桩的自由冻胀试验; 2 . 根 据相似性原理, 在室内试验过程中调整冷端温度 与几何尺寸以缩短冻结时间; 3. 推导得到 6 种桩 型冻拔量与冻结深度的定量关系。

方 法: 1. 通过相似性原理确定试验条件, 模拟实际工况 中的降温冻结过程； 2 . 观测此过程中 5 种螺旋桩 型的温度场、冻拔量和土压力随时间的变化规 律, 并设置一组光滑桩作为对比; 3. 根据冻拔量 大小选取最优桩型, 并推导冻拔量与冻深的定量 关系。

结 论: 1. 螺旋桩冻拔量小于光滑桩, 验证了螺旋桩抗冻 拔的有效性; 采用不同土样有相同规律。2. 冻深 达到 $0.9 \mathrm{~m}$ 的季冻区, 双螺旋大叶片桩抗冻拔效 果最好; 螺旋叶片建议设置在非冻区; 冻拔量大 小关系为: 双螺旋大叶片桩 $<$ 半螺旋大叶片桩 $<$ 半 螺旋小叶片桩<双螺旋小叶片桩<全螺旋桩<光滑 桩。3. 得到 6 种桩型冻拔量与冻深的线性关系。

4. 土中水开始冻结时土压力增大, 含冰量稳定后 土压力变化很小。

关键词：季节性冻土区；螺旋桩；冻胀；相似性原理； 冻拔 